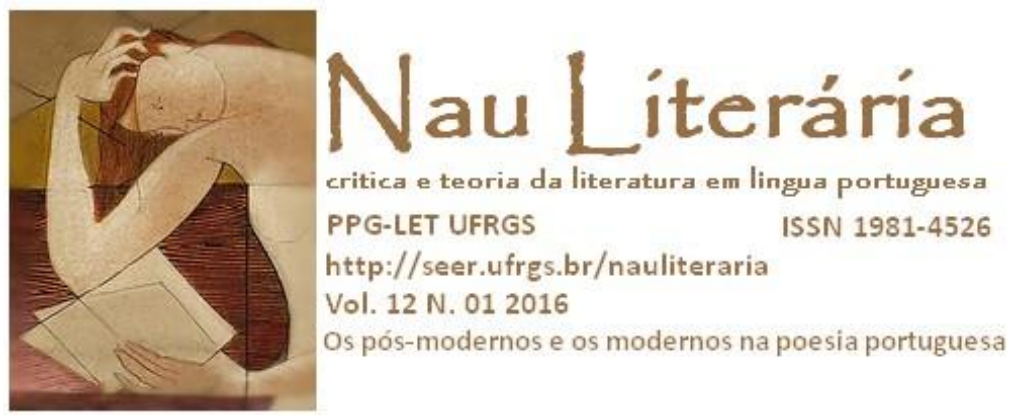

\title{
Para uma arte poética em José Luís Peixoto
}

\author{
José Luís Peixoto's Art of Poetry
}

Alexandre Kuciak ${ }^{1}$

RESUMO: Este ensaio pretende analisar uma suposta poética contida em "Arte poética", primeiro poema do livro A criança em ruínas, de José Luís Peixoto. Parece haver, neste poema, uma reflexão sobre a poesia em conjunto a uma tentativa de justificação das escolhas repertoriais do poeta.

PALAVRAS-CHAVe: Poesia - Poética - Poesia portuguesa - Imagem poética.

ABSTRACT: This article analyzes a supposedly art of poetry found in "Art of Poetry", first poem of the book The Child in Ruins, of José Luís Peixoto. There seems to be, in this poem, a reflection on poetry together with an attempt to justify the poet's repertory choices.

KEYWORDS: Poetry - Poetic - Portuguese poetry - Poetic image.

\section{A estrutura inicial e alguma intertextualidade}

José Luís Peixoto começa A criança em ruínas (2001) com “Arte poética”, único poema do livro a receber um título. Além dessa distinção, o poema é seguido por outras três páginas. A primeira e a terceira em branco e a segunda contendo o número "1" seguido de um ponto. Isso não acontecerá com nenhum outro poema. Os poemas seguintes se sucederão regularmente; no momento em que um terminar, na página seguinte começará o próximo. Por esses dois índices, o título e as páginas em branco, "Arte poética" não apenas ganha destaque, mas também é separado dos outros poemas de A criança em ruínas. Pertence ao livro, contudo, não dialoga com ele da mesma maneira como fazem os outros poemas entre si.

\footnotetext{
${ }^{1}$ Doutorando em Letras/ Estudos de literatura: Literatura, Sociedade e História da Literatura da UFRGS.
} 
Anuncia os outros poemas, mas mantém-se deslocado. Anuncia esta criança em ruínas, mas não a torna o centro da reflexão. Esse recurso se assemelha ao "prólogo", seja o do teatro grego, o das óperas, ou o dos romances. O prólogo é sempre uma primeira parte, uma parte com frequência estranha ao que virá a seguir. O prólogo pode ser um monólogo, uma conversa, uma introdução à história. A função do prólogo é chamar a atenção e desaparecer, passando a atuar de forma inconsciente enquanto a trama se desenrola. Essa estrutura, também ocupada pelo coro na Grécia, manteve-se sempre nas obras literárias e nos chegou de forma praticamente inalterada. Talvez a poesia seja, dentre as artes escritas, a forma em que menos esperamos um "prólogo", visto que o caráter explicativo, ou didático, de um poema, é um problema em si durante a criação poética. Assim, a presença desse poema "apartado" dos demais, nos chama a atenção também para outro aspecto: uma necessidade do poeta de ilustrar os poemas que virão utilizando uma estrutura mais comum à narrativa em prosa. Propositalmente ou não, na estrutura inicial do livro já há um diálogo entre poesia e prosa.

O segundo momento em que essa relação se possibilita é no título do poema. Desde Aristóteles, uma "poética" é uma espécie de tratado no qual são evidenciados os processos e os componentes das criações artísticas. Normalmente, as poéticas são escritas em prosa, com uma estrutura que visa a "revelação" ou clarificação de elementos que tornam o fazer poético bom ou não. Nas reflexões de Aristóteles sobre o conceito de mimesis em Arte poética, o objeto artístico possui autonomia, podendo superar e transcender o objeto original no qual se inspirou. A imitação se faz por meio de propriedades específicas das formas artísticas e se dá sempre dentro de uma dualidade:

a) reprodução: relação entre obra artística e realidade ou natureza, o que está dentro e o que está fora da obra;

b) construção: o objeto artístico com construção própria, organização interna e propriedades ficcionais.

Mas como traduzir essa estrutura para a poesia? Temos, assim, a inclusão, por Peixoto, de uma espécie de "prólogo" e de uma "poética", dois elementos que, por si só, já carregam uma relação essencial com uma estrutura. A escolha de Peixoto para estes elementos em seu primeiro poema talvez funcione justamente porque eles estão em um livro de Peixoto. O modo de fazer poesia do autor, com frases longas, tom prosaico e simples, reflete uma "arte poética" que facilita a inclusão de elementos vindos da prosa, enriquecendo e expandindo as relações entre o campo da prosa e da poesia. O resultado dessa combinação 
será uma arte poética em que se valorizam as descrições de instantes vividos em benefício de uma metodologia do poema.

O terceiro momento em que é possível entrever uma relação entre poesia e prosa (verificando apenas a estrutura do poema), é o número “1” seguido do ponto, na página localizada entre as duas páginas em branco. Na prosa, também é com esse número que normalmente busca-se indicar uma organização, o começo de um trabalho fechado como, por exemplo, um romance. Pela terceira vez temos uma ideia de sistema: prólogo, poética, capítulo.

\section{$2 \mathrm{~A}$ arte poética peixotiana}

\section{Arte poética}

o poema não tem mais que o som do seu sentido, a letra p não é a primeira letra da palavra poema, o poema é esculpido de sentidos e essa é a sua forma, poema não se lê poema, lê-se pão ou flor, lê-se erva fresca e os teus lábios, lê-se sorriso estendido em mil árvores ou céu de punhais, ameaça, lê-se medo e procura de cegos, lê-se mão de criança ou tu, mãe, que dormes e me fizeste nascer de ti para ser palavras que não se escrevem, lê-se país e mar e céu esquecido e memória, lê-se silêncio, sim, tantas vezes, poema lê-se silêncio, lugar que não se diz e que significa, silêncio do teu olhar de doce menina, silêncio ao domingo entre as conversas, silêncio depois de um beijo ou de uma flor desmedida, silêncio de ti, pai, que morreste em tudo para só existires nesse poema calado, quem o pode negar?, que escreves sempre e sempre, em segredo, dentro de mim e dentro de todos os que te sofrem. o poema não é esta caneta de tinta preta, não é esta voz, a letra $\mathrm{p}$ não é a primeira letra da palavra poema, o poema é quando eu podia dormir até tarde nas férias do verão e o sol entrava pela janela, o poema é onde eu fui feliz e onde eu morri tanto, o poema é quando eu não

conhecia a palavra poema, quando eu não conhecia a letra p e comia torradas feitas no lume da cozinha do quintal, o poema é aqui, quando levanto o olhar do papel e deixo as minhas mãos tocarem-te, quando sei, sem rimas e sem metáforas, que te amo, o poema será quando as crianças e os pássaros se rebelarem e, até lá, irá sendo sempre e tudo. o poema sabe, o poema conhece-se e, a si próprio, nunca se chama poema, a si próprio, nunca se escreve com $\mathrm{p}$, o poema dentro de si é perfume e é fumo, é um menino que corre num pomar para abraçar o seu pai, é a exaustão e a liberdade sentida, é tudo o que quero aprender se o que quero aprender é tudo, é o teu olhar e o que imagino dele, é solidão e arrependimento, não são bibliotecas a arder de versos contados porque isso são 
bibliotecas a arder de versos contados e não é o poema, não é a raiz de uma palavra que julgamos conhecer porque só podemos conhecer o que possuímos e não possuímos nada, não é um torrão de terra a cantar hinos e a estender muralhas entre os versos e o mundo, o poema não é a palavra poema porque a palavra poema é uma palavra, o poema é a carne salgada por dentro, é um olhar perdido na noite sobre os telhados na hora em que todos dormem, é a última lembrança de um afogado, é um pesadelo, uma angústia, esperança. o poema não tem estrofes, tem corpo, o poema não tem versos, tem sangue, o poema não se escreve com letras, escreve-se com grãos de areia e beijos, pétalas e momentos, gritos e

incertezas, a letra p não é a primeira letra da palavra poema, a palavra poema existe para não ser escrita como eu existo para não ser escrito, para não ser entendido, nem sequer por mim próprio, ainda que o meu sentido esteja em todos os lugares onde sou, o poema sou eu, as minhas mãos nos teus cabelos, o poema é o meu rosto, que não vejo, e que existe porque me olhas, o poema é o teu rosto, eu, eu não sei escrever a palavra poema, eu, eu só sei escrever o seu sentido. (PEIXOTO, 2007, p. 7-9)

O tema principal do poema "arte poética" é o poema. Por ser uma poética, espera-se que o eu lírico nos diga o que é um poema, e como devemos proceder para ter sucesso ao elaborá-lo. Contudo, até a metade do poema, o eu lírico será capaz apenas de dizer o que o poema não é. Começará tateando, até chegar às imagens dos pais. A partir deste momento, ao entrar em confronto com o silêncio deixado por estes é que o eu lírico afirmará o que o poema é, de fato, na sua concepção. Como se verá, sua resposta do que é se fundará essencialmente nessa relação de perda que viveu.

Busca-se o aspecto básico do poema, um poema atemporal, um poema-essência. Afirma-se o que pertence ao poema: o som, por ser o que realmente importa - o restante juntaria os acréscimos. O som é apresentado como estritamente ligado ao sentido, "o som do seu sentido", pois o poema transmite a sua mensagem pelo som, porque é linguagem, porque, por ser poesia séria, está preocupado com o resgate do sentido verdadeiro das palavras, com aquela relação sugerida por Sócrates, a Crátilo e a Hermógenes, em que a essência da coisa pode ser revelada no nome e, em um nível mais próximo do mimético, pelas letras individualmente. A letra "s", por exemplo, é frequente no primeiro verso de Peixoto em "Arte poética". Diz Sócrates, em Crátilo: "o som do seu sentido": "pelas letras que comportam uma aspiração, o "ph", o "ps", o "s" e o “z”, são imitadas todas as coisas deste tipo, como por exemplo, o frio (...), a agitação" (PLATÃO, 2010, p. 129). O "s" é um som que quase não 
soa, um sopro, um assovio, mas acima de tudo, é um som, e por ser som, diz. E elementos como o "sopro", o "assovio", ou o próprio "som", são elementos simples, mas que, ao mesmo tempo, não são, a exemplo da poesia em si ou do fazer poético de José Luís Peixoto: uma combinação de simplicidade e clareza que facilita a compreensão influindo, simultaneamente, uma sensação de complexidade.

O poema é seu som e seu sentido. Simples. Peixoto logo torna essa "coisa-poema" ainda mais simples. Foca na palavra, mais especificamente, na primeira letra da palavra que representa essa "coisa-poema", a letra "p". Fica mais claro, ao leitor, que o poema de que se fala é tudo o que a palavra "poema" representa. O foco é uma letra, que ao mesmo tempo é um som chamado de letra. Assim como o poema, que pode ser observado pelo seu sentido fora de sua relação com seu som, essa letra é observada por algo que ela não é: "não é a primeira letra da palavra poema". Tem-se uma ideia do que é através do que não é. No caso, afirma-se algo que vai contra o óbvio, observável a priori, ou seja, problematiza nosso olhar para as palavras, para as letras. O óbvio não é óbvio. A aliteração do segundo verso em "p" e "e" repete as letras presentes na palavra "poema", circundando uma palavra que origina tudo.

Diante da complexidade do poema, sem afirmar nada sobre o que de fato o poema é, o eu lírico apenas diz o que o poema não tem, o que não é, e passa a falar de como o poema é feito: "esculpido". Esculpido como uma estátua? Semelhante à materialização de uma figura pelo mármore, os sentidos de um poema são trabalhados com delicadeza, com cuidado, com paciência. Seguindo o raciocínio, pode haver um molde de uma estátua, assim como há uma forma pronta para um poema como a ode ou, mais fechado, o soneto. Pois em Peixoto, a forma se forma. Este poema assim, soa logo como a justificação do repertório do autor, de seu estilo prosaico, simples, com frases ora muito longas, ora curtas. Temos no terceiro verso, como temática, o processo e a forma do poema. Um poema se faz com sentidos, com palavras trabalhadas. O "poeta-escultor", diante do mármore, pode até possuir uma forma em mente, mas essa forma irá se confirmar, ou revelar, somente após ter seus sentimentos postos em sentidos. Então o mármore será poesia. Esta é a primeira grande imagem desse poema, cujo principal referente parece ser uma abstração, no caso, a própria poesia. Temos um "poetaescultor" e um "poema-mármore". Pondo em prática o cuidado que sugere, Peixoto garante a sensação que propõe em seu verso com a assonância em "i" ("esculpido de sentidos"), uma letra cuja forma gráfica remete a uma ferramenta de acabamento. Esse método de Peixoto, de 
propor um modo de fazer poesia e imediatamente o exemplificar, será recorrente no restante do poema.

Propõe o autor: a palavra poema não é um poema. Novamente, afirma o que não se faz. A leitura do poema, dessa vez, é problematizada. Não devemos ler um poema, mas ler seu significado, afinal, o poema é o seu sentido. Não lemos um poema. Lemos palavras, e no caso de Peixoto, palavras simples, como pão, como flor. O pão é um alimento básico. A flor contém uma beleza natural, poderia se dizer também básica, como a erva. Há a preferência por palavras simples na poesia de José Luís Peixoto, a elementos presentes aos tempos históricos mais remotos. A repetição da palavra "ler", a partir do quarto verso, reforça o caráter de uma leitura infinita e que não esgota sentidos. Enumeram-se as imagens, imagem de alimento, de beleza, de natureza. As três ordens, relacionadas com a vida - como o poema. O poema pode alimentar como o pão, pode encantar como a flor, pode ser algo daninho como a erva. A erva, entretanto, é fresca. Seria uma erva ao sol? Algo não tão daninho, por ser poema? A imagem da erva só se completa no verso seguinte. Algo que era simples, "erva", ganha um sentido, talvez, metafórico, graças ao verso seguinte: "poema não se lê poema, lê-se pão ou flor, lê-se erva/fresca e os teus lábios, lê-se sorriso estendido em mil”.

O que era simples, ganha mais sentidos. O sentido estava sendo esculpido, por isso a suspensão temporária no verso anterior? Porque não deixar na linha anterior a palavra "fresca"? Para dar esse efeito de construção, de ponderação do sentido, era preciso cortar o verso. O poema fez a sua forma. O poeta propôs a imagem do poeta-escultor e em seguida apresentou um exemplo de sua escultura. Ainda se dá ao poema mais um sentido, o dos lábios de alguém que não sabemos. Lemos por trás dos sentidos um sentido que é particular ao poeta, um ser humano que o motiva. Esse "teu" também é nosso, pois lemos os lábios que nos são importantes também. A imagem dos lábios remete, imediatamente, a sorriso. No caso, um sorriso estendido. Um significante puxa o outro. O significado só se revelará no próximo verso. Agora, temos outro sentido em suspenso, um sentido que poderá dar sentido ao sorriso.

O "sorriso estendido" pode ser uma hipálage. O eu lírico atribui ao substantivo "sorriso" uma qualidade pertencente, em termos lógicos, a outro substantivo. Nesse caso, o ser humano está estendido sob árvores e o sorriso se refere à sensação de agrado dessa posição. Outra interpretação também poderia ser a do próprio sorriso, largo, diante das árvores. Pela associação de significados, no poema, logo esse sorriso também pode se estender, como o céu. Complementa a simplicidade das árvores, que nos remetem à beleza e à 
companhia do outro, devido à menção ao sorriso. O céu ainda pertence à imagem anterior, mas o céu esconde um outro significado. Pode-se sorrir para algo que não compreendemos. Esse céu é perigoso. No caso é um "céu de punhais" e a imagem do punhal remete ao punho fechado, a algo que vem contra o indivíduo. "Ameaça": a palavra não deixa dúvida para a interpretação do sentimento. O poema é um sorriso que se estende sob a beleza e sob a ameaça? Poema também é medo. Medo de quê? Relacionado à procura, podemos dizer um medo de encontrar, medo da descoberta de si.

A procura ganha a imagem do cego. O poema procura os que não podem enxergar. Quererá fazê-los ver? Ou seria um tatear o mundo através das palavras? Conhece-se o mundo pelas palavras, assim, somos cegos, de certa forma, ao mundo. A imagem do cego remete à imaginação, à descoberta, como a da criança. "Lê-se mão de criança", nos remete à poesia escrita na mão. E a mão logo nos remete à leitura de mãos: método minucioso como o da leitura do poema. O paralelismo acaba com a referência à mãe, imediatamente após a da criança. Assim, ganha destaque no poema, a mãe, figura feminina, criadora da vida, enquanto poesia que se lê. Ela surge como uma força que não cabe no paralelismo, como se o discurso não se controlasse ao descrevê-la, como se a imagem da mãe fosse tão poderosa e forte que não se deixa aprisionar pela síntese. Passa a dar forma ao poema, como uma parte do mármore que não se deixa lapidar, que precisa de destaque. O paralelismo só retornará quando o poeta parar de falar da mãe, mas, ainda assim, com uma outra imagem, que, de certa forma, também é uma mãe (o país). A mãe, figura destacada, está morta? Além de "dormir" as palavras "mão" e "mãe", na mesma linha, podem carregar a imagem do corpo deitado no caixão com as mãos sobre o peito. Imediatamente surge a imagem do nascimento, "me fizeste nascer", que soa como algo forçado, sem escolha, violento.

A existência se dá por palavras, mas a existência é diferente das palavras, embora seja palavra. Então há o retorno ao paralelismo sobre o que "lê-se" enquanto se lê poesia. Surge a imagem do país, algo posterior, criado pela linguagem, mas com raiz semântica próxima à de mãe enquanto "berço", "casa" de indivíduos. Depois segue a imagem do mar, algo que também estava lá antes da linguagem, como a mãe. Assim como o céu, imagem seguinte, porém, um “céu esquecido" que pode nos remeter à religião ou à sua falta. É o segundo céu do poema. O primeiro, ameaçava, com punhais, o segundo, não mais ameaça. Podemos encontrar relação entre um céu que ameaçava, o céu de Deus, que ameaçava a todos com um “não lugar” à sua direita, e que agora não tem mais força, pois é memória. A imagem do céu 
representa o lugar onde está a mãe? Ou significa que já começou o processo de superação? Ainda, pode-se dizer que após o falecimento, perdeu-se a fé.

A memória produz poesia, assim como o silêncio. O silêncio provocado pela morte, o silêncio da memória que não quer relembrar ou que não consegue mais. Seria, entretanto, um silêncio após a memória ou no lugar da memória? O silêncio produz uma pausa no poema, quebrando novamente o paralelismo. Há muito silêncio no verso, logo após a mãe, após a mudança na imagem do céu. O silêncio é tão forte que quebra o paralelismo definitivamente. Passa-se a tentar compreender este silêncio. Octavio Paz, em $O$ arco e a lira, chama a atenção para os aspectos do poema como a pontuação. "A poesia é conseguir transformar um ponto final, uma vírgula, um ponto de exclamação, em poesia” (PAZ, 1992, p. 56-58). Ou seja, como dar forma poética a uma pausa? Como o silêncio provocado por uma perda chega a ser poesia? O poema é um silêncio disfarçado, transformado? O silêncio é um lugar para o qual nossa mente recorre? Para o eu lírico de Peixoto, sim, o silêncio é um lugar. Chegamos nesse lugar através de um olhar de uma "doce menina" - outra imagem feminina, em meio a um verso ("olhar de doce menina") que dialoga com a popular relação entre o olhar e as mil palavras. Sentimos muito mais um olhar, seja amoroso ou de desprezo, do que palavras. Essa figura feminina infantil, conversava com o eu lírico aos domingos (sob as árvores?), entre beijos que geravam silêncio e uma "flor desmedida". Segunda aparição da flor, ela deixa de ser simples flor para ganhar outro sentido no decorrer do poema. Desmedida pode ser em relação ao tamanho dela, uma flor arrancada de um campo ou uma flor dada em um momento inoportuno (e que gerou o silêncio). Em meio a essa infância surge outro silêncio importante, o silêncio da figura paterna, que "morreste em tudo". Outra perda, associada à ideia de uma existência simples. O pai vivera uma vida simples, simples como as palavras e a forma poética do eu lírico. Não fosse o poema dele, o pai não teria sequer "existência", num gesto do eu lírico de valorizar um ser humano apagado da história por sua insignificância. Mas existe "calado". É dentro do poeta que a figura do pai "escreve" com, talvez, seu silêncio característico ou, mais provável, com o silêncio que sua perda provocou em todos. $\mathrm{O}$ sofrimento faz com que o eu lírico escreva sobre esse silêncio.

Há uma motivação para o escrever. $\mathrm{O}$ ato de escrever vem de um abismo silencioso dentro do eu lírico. Mas o poema é "calado", pois não é a "caneta de tinta preta", tampouco “esta voz” do eu lírico, tampouco as letras. O eu lírico, pela primeira vez, começa a afirmar o que o poema é, e não enumera características formais, como se espera de uma poética, mas 
fala de vivências, de um mundo que não o da ficção. O diálogo com a mimesis aristotélica se faz perceptível. A relação entre obra artística e a matéria real, entretanto, privilegia o que está dentro do poeta, que quer virar palavra, e por consequência forma poética. A palavra não consegue ser mais forte do que o que está fora da obra. Ao mesmo tempo, o eu lírico está construindo, em sua poética, um objeto artístico e delimitando a sua organização interna ao enunciar e executar as suas "intuições", se podemos chamar assim, sobre as propriedades da ficção. Desta forma, o caráter mimético é rebaixado diante do caráter do que se busca representar.

Semelhante a Alberto Caeiro, para o eu lírico do poema "Arte poética" a poesia são os momentos vividos (PESSOA, 2008, p. 13). Num primeiro momento, as imagens construídas são alegres. A criança dormindo com o sol entrando pela janela, comendo torradas sob o lume da cozinha, correndo para abraçar o pai. Em ambas imagens, a criança revive momentos nos quais seus pais estavam vivos, quando seu sono era tranquilo. A poesia é quando se levanta o olhar do papel para tocar um ser que ama. Um poema não é um poema, pois "poema" é uma palavra. Poema é sentir as coisas com o corpo e não com a imaginação. Quando volta às propriedades da ficção, o eu lírico condena a metáfora e a rima, condena quem julga conhecer a raiz das palavras: "não possuímos nada".

Num segundo momento, a poesia carrega imagens de perda: um afogado, um pesadelo e combina dois sentimentos, angústia com esperança. Em seguida, novas imagens representando os momentos vividos apresentam o grão de areia, os beijos, as pétalas e os gritos (associados às incertezas). As propriedades da ficção questionadas agora são as estrofes, os versos, as letras. O poema termina com a imagem de um cabelo sendo acariciado, de duas pessoas se olhando.

As imagens deste segundo momento e as duas imagens finais são as mais desconexas e difíceis de compreender. Se buscarmos analisar o poema nos termos de Octavio Paz, como uma grande imagem, teríamos um fazer poético marcado pela perda e que busca, na medida do possível, transmitir os efeitos desta perda, sendo essa tentativa um aprendizado por si só. Nas imagens finais temos uma rede de relações tão presente que pode nos levar a um exagero interpretativo. Contudo, se mantivermos os índices que o poema nos ofereceu até o momento dessas novas imagens, no caso, a relação com as imagens anteriores, talvez seja possível acomodá-las, não com fim redutivo, mas como busca de produção de conhecimento através da produção de imagens. 
$\mathrm{O}$ afogamento pode ser associado à perda dos pais ou a de alguém querido. $\mathrm{O}$ pesadelo, uma elaboração da mente onde nos confrontamos com algo que nos causa um sentimento negativo, podendo referir-se às lutas internas do eu lírico após o acidente. Ainda temos mais um índice, os dois sentimentos logo após as duas imagens. Podemos concluir que a angústia decorre da lembrança ou do momento do afogamento? E que a esperança venha do confronto com seus fantasmas, princípio de superação da angústia persistente? As imagens do grão de areia podem remeter à menina que o eu lírico beijara anteriormente, devido à nova referência às flores (antes era uma flor desmedida). Uma vez que o afogamento foi trazido pelo eu lírico, é imediata a associação do grão de areia com a praia e à indução de que um belo momento vivido foi interrompido (por gritos). Considerando apenas este poema, apartado do conjunto de $A$ criança em ruínas, estaria o eu lírico tentando nos dizer que quem foi afogado teria sido a sua amada? O que nos faz aproximar a imagem do afogamento da imagem da menina, ao invés dos pais, são as imagens finais, que surgem com uma força enorme: momentos de intimidade vividos por duas pessoas, momentos singelos, um passar de mãos nos cabelos e um olho no olho. A imagem do poema, assim, deixa de ser o próprio poema, enquanto abstração e passa a se referir a uma imagem simples em que dois seres humanos se enxergam. A poesia não é uma série de preceitos, uma receita, não é possível colocá-la no sistema de uma poética. A poesia se relaciona com os momentos únicos. A poesia é "minhas mãos nos teus cabelos".

O que pode parecer uma destruição da poesia, novamente é, em boa parte, justificativa pessoal. A palavra poema existe e é preciso, de certa forma, honrá-la, não buscar compreendêla. Nós vivemos, as palavras vivem e há uma harmonia entre todas as coisas, uma propriedade mimética não apenas gerada pelos seres que possuem linguagem, mas por cada uma das coisas do nosso planeta, teoria comparável à "teoria das semelhanças" de Walter Benjamin (BENJAMIN, 2008, pp. 108-113): “ainda que o meu sentido esteja em todos os lugares como sou”. Isso tudo é o poema e por essa razão não é possível escrever a palavra, mas apenas como essa poesia atinge o indivíduo. Se o leitor esperava o caráter descritivo de uma poética, de um lado se frustra, pois não há uma lista de procedimentos seguros. Por outro lado, recebe uma outra poética, fundada na negatividade. Negam-se recursos formais que caracterizam a poesia pois, para saber o que ela é, necessita-se, primeiramente, desconhecer a própria palavra, já carregada de tantos vícios. A poesia que o eu lírico desse poema de José Luís Peixoto conhece reconhece que a poesia não está nas letras ou em técnicas formais. Entretanto, é uma poesia que sente a poesia no mundo. 


\section{REFERÊNCIAS}

ARISTÓTELES. Poética. Trad. Eudoro de Sousa. Porto Alegre: Globo, 1966.

BENJAMIN, Obras escolhidas. São Paulo: Brasiliense, 2008. v.1: Magia e técnica, arte e política, p. 108-113.

HUTCHEON, Linda. Poética do pós-modernismo. Rio de Janeiro: Imago, 1991.

PAZ, Octavio. O arco e a lira. Rio de Janeiro: Nova Fronteira, 1982.

PEIXOTO, José Luís. A criança em ruínas. 6.ed. Vila Nova de Famalicão: Quasi, 2007.

PESSOA, Fernando. Alberto Caeiro: poemas completos. São Paulo: Nobel, 2008.

PLATÃO. Crátilo. Trad. Luciano Ferreira de Souza. São Paulo: Universidade de São Paulo, 2010.

TODOROV, Tzvetan. Symbolisme et interprétation. Paris: Seuil, 1978. 